\title{
Trajectories of social change in the development of Nepal's countryside: Some sociological reflections
}

\section{Youba Raj Luintel}

\section{Abstract}

This paper explores dynamics in the capitalist market relations in Nepal's agricultural sector and the resultant structural social change in Mahesh Khola, a village west of the capital city, Kathmandu. I have studied a case of the Mahesh Khola valley during a couple of decades, from 1985 to 2008, to examine the expansion of agricultural markets as a mechanism to transform rural livelihoods into the maket-operated capitalist set up. In this research work, I would unfold how a process of transformation of agricultural sector replicates a real development of the rural sector, resulting in social disruptions and widening social inequalities. I juxtapose such a long-term social change I discerned in Mahesh Khola with other studies of similar kind, one in Thak village, closer to Pokhara (Macfarlane, 2001) and the other along the corridor or Siddhartha Highway, from Lumbini to Pokhara (Blaikie et al., 2002). In doing so, my emphasis will be on investigating how the society-market interface evolved in the dynamics of an agrarian society.

Keywords: social change, countryside Nepal, agriculture, market-centered development, Introduction

This paper explores social change that unfolds in a long-term. Such a durable social change does not connote an evolutionary kind, nor does it follow social change of functional kind. Sociological understandings of social change differ profoundly with other social sciences in their treatments of social change in the sense that sociology postulates social change of structural kind.

This paper is divided into three parts. In the following section, I briefly conceptualize social change from sociological standpoint. I primarily follow Norbert Elias. This will be followed by an empirical section, in which I pull three different empirical cases from countryside Nepal, each of which either revisits the original research sites after a gap of two or three decades to see what changes have taken place, or take longer retrospective view of social change for more than two decades. Finally, this paper concludes by making a synthetic analysis on these case studies in the light of theoretical premise that it sets out.

This paper primarily argues that understanding of social change should be sociologically informed. Sociological approach to social change is always social structural - meaning that, social change needs to be looked at social structures and institutions, which demands a long-term retrospective studies. At its empirical ground, I would support the argument of social change with subclaims that one cannot miss out the structural alteration that long-term social change eventually manifests into in the case of countryside Nepal. In that sense, embedding class analysis in the broader contexts of examining market dynamics are the two arenas of social change studies, which would unravel an ever 
-icreasing trend of widening and deepening social inequality.

\section{Conceptual premise}

The study of social change is at the very core of sociology. But the problem is how should one define social change (see Sztompka, 1993: 6; Dahrendorf, 1959: 127; and Collins, 1990)? Classical sociologists, since the time of Auguste Comte (17981857), have been divided in the ways they explained it and there is still a lack of a coherent and unified framework of analysis. The diverse interpretations of social change in contemporary (Jordan and Pile, 2002; Noble, 2000; Sztompka, 1993; Boudon, 1986; Etzioni-Halevy, 1981) and classical (for example, Hawley, 1978; Chirot, 1977; Hernes, 1976; Lenski, 1976; Smith, 1973; Swanson, 1971; Parsons, 1970; Barth, 1967; Smelser, 1967; Zollschan and Hirsch, 1964; Moore, 1963; Hagen, 1962) sociology literature are a case in point.

Sociological understanding of social change has developed primarily along two streams of contesting arguments. While functionalists (such as Parsons, 1970) would understand it in terms of modernisation, for the Marxists and the political economists, however, a historical understanding of the changing forms of class relations would reveal its true essence (Holton, 1985; 1981). ${ }^{1}$ Hence the debate

1. A more concrete framework of analysis of social change comes from Marx and his followers. Despite sharing broadly an evolutionary scheme, the Marxian explanation of social change combines (a) productive forces with (b) dynamics of class relations. The central tenet of Marx is that "...the continuing development of productive forces changes the relations between classes, and the condition of their conflict" (Bottomore, 1987: 274). still continues as to what should constitute the central locus in a proper understanding of social change. But, to Norbert Elias, in order to have a true understanding of social change one should focus on "increased differentiation and integration," as well as "decreased differentiation and integration" (Elias, 1994: 182ff), which together form the two main directions in the structural changes of societies.

Sociologically relevant social change, to Elias, is a process of structural change, which he argues, may be reflected in personality structures and which demands that a longterm account of the process of change be considered. Social change in this sense is often non-linear and cumulative. Such a social change that the three research works focus is certainly not a linear type, nor an evolutionary one in the nineteenth century. It broadly resonates what Elias argues:

A concept of social change that does not distinguish clearly between changes that relate to the structure of a society and those that do not - and, further, between structural changes without a specific direction and those which follow a particular direction over many generations, e.g., toward greater or lesser complexity - is a very inadequate tool of sociological inquiry. (Elias, 1994, p. 184)

Following Hawley, I reiterate that we should focus more on nonrecurrent changes of irreversible kind. In his presidential address to the American Sociological Society in the late 1970s, Hawley argued that an account of social change should look at "nonrecurrent alteration of a social system considered as a whole" (Hawley, 1978, p. 787). This definition demands that an account of social change should primarily focus on (a) medium to longterm alterations and (b) which are system- 
wide. Hence, only the sustained changes that leave some marks in the very structure of the society can truly be considered social change (see Hernes, 1976 for details). This is how the present research explicates social change as a structural process of social transformation in terms of class dynamics. And, at the very core of this structural transformation, there lies a powerful and pervasive force at work, which is the market, specifically, the capitalist market.

In this paper, I will refrain from looking into changes over "many generations" to identify "a figurational change," as Elias did in his quest for the process of state formation and civilisation building (Elias, 1994: 184). In this paper, I investiage into the structural social change unfolded in three research sites in respective time frames with an aim to identify a discernible pattern in long-term social change. In doing so, my emphasis will be on investigating how the society-market interface evolved and how did it articulate in the dynamics of an agrarian society. Here Elias cautions us that looking at changing class figurations in understanding structural social change will remain less fruitful if such changes are not looked at in the wider context of their articulation with larger processes, such as the expansion of the capitalist market, for example.

\section{The trajectories of long-term social change}

In this section, I attempt to bring three different studies together (Macfarlane, 2001, Blaikie et al., 2002, and Luintel, 2010) to reveal the trajectories of long-term social change being unfolded in Nepal's countryside. Theses case studies span a period of last five decades (1970s onward). These studies are carried out by different scholars on different time periods and in different geography of the country. They also follow quite distinct methodological and theoretical approaches. In that sense each of these studies is unique. What brings them closer is their broader overview on Nepal's long-term social changes, particularly in its countryside, during this period.

Trajectory 1. Alan Macfarlane's reflection on 30 years of change in Thak (a village in Nepal's mountain region near to Pokhara) entitled "Sliding down hill" (Macfarlane, 2001) builds on its original study Resources and Population (Macfarlane, 1976). Macfarlane's account contributes enormously to expanding our understanding of long-term social change in the specific context of Nepal. Although Macfarlane's account "does not make a pleasant reading" because it reports "a move [of Thak] from bad to worse" (Luintel, 2001, p. 112) with details that people have become thinner and more unhealthy, the livestock population has depleted, farm productivity has plummeted, the real earnings of village workers have shrunk leading to the staggering indebtedness of the village households; and all this resulted in unforeseen "extensive and permanent outmigration" (Macfarlane, 2001, p. 106).

It also reports that despite some economic improvements, owing to army recruitment or overseas labour migration, the inhabitants of Thak neither sent part of their income back home, nor they themselves came back to Thak. They would rather settle in nearby towns, in this case Pokhara. To Ben Campbell, Thak's case shows that a place that was to inspire so much development activity in the hills remains in a state of under-investment. The peripheralisation of Thak, he argues, in relation to the growth in urban conglomerations, in some ways shows the fate of Nepal's other rural communities (Campbell, 2001). 
In both Resources and Population (Macfarlane, 1976) and "Sliding down hill" (Macfarlane, 2001), there are a number of flaws, some methodological and others analytical. To both Campbell and Luintel, Macfarlane's account misses out the larger context in which social change unfolded in Thak. Macfarlane developed a picture of social change as if it were independent of a larger political economic context, such as, the expansion of the market and capitalist encroachment on the one hand, and the international division of labour on the other. Macfarlane's admits that his prediction (of "no forest in Thak by the year 2000") that he did in his doctoral research (Macfarlane, 1976) turned wrong. Such a capitalist mode of social change steadily prompts a new population process (such as outmigration) coming into effect. To both McHugh (2001) and Seddon (2001) who reviewed Macfarlane's account, it fails sufficiently to recognise the analytic importance of social divisions and class inequality in Thak. These are some of the social dynamics that emerged so robustly in his recent reflection (but Macfarlane still fails to recognise them). Had Macfarlane opened his mind to a slightly different analytic route, such as, for instance, including some treatment of the political economy of class, it would have better enabled him to grasp the internal dynamics of the long-term social change in Thak between the mid-1970s and the turn of the century.

Macfarlane can also be challenged for his analytic weakness in according little value to the agency of the people in question. For instance, in his original research, Macfarlane posited his research subjects as entrapped in external ecological conditions. Later in his reflection, he portrayed urban growth (in Pokhara) as a new externality to his research subjects. In either case, his account posited ecological conditions or urban development as overpowering to the community as if people did not have any capacity to adjust, adapt or reposition the ways they lived.

Trajectory 2. A year after Macfarlane brought his reflection to a broader academic attention, a group of British scholars from East Anglia University, namely Piers Blaikie, John Cameron and David Seddon (Blaikie et al., 2002) published a little more rigorous reflection based on their re-survey of 20 years of change in the lives and ideas in some of their original research villages from west central Nepal (that literally spanned from Pokhara to Lumbini). Their research reflects upon their original account of the highly popular, Nepal in Crisis (Blaikie et al., 1980), for which they had originally conducted field-research during 1974-75. Their original research into the political economy of agrarian change in Nepal drew an overall conclusion that Nepal was, in the mid-1970s, in a state of crisis, fundamentally rooted in a failure of productive organisation associated with its economic and political underdevelopment.

Such a pessimistic conclusion of Blaikie and his colleagues (Blaikie et al., 1980) resonates in many respects with Macfarlane's mentioned above. The origins of Nepal's crisis, they saw, were derived partially from the particular form of imperialism experienced by Nepal which allowed it to maintain formal political autonomy vis-à-vis its giant neighbour, India - a point Macfarlane missed out completely. Their original study showed that while Nepal's experience as "semi-colony" ensured a degree of "forced stagnation" in its production and productivity sectors, it also led to an increased population pressure on marginal land, emigration, and ecological decline (Blaikie et al., 1980). 
Following an analytical framework that combined class analysis with dependency theory, their original study found a dynamic which they anticipated would lead to capitalist development in the rural (and urban) areas of west central Nepal. The re-survey in the same region after a gap of 20 years, however, showed it to be otherwise. Seddon writes elsewhere that:

The most pessimist forecasts of the mid1970s [in Nepal in Crisis] regarding the pauperization of the mass of the peasantry in the region had not been realized and that a significant 'middle peasantry' had managed to survive through a variety of livelihoods strategies, including labour migration to other areas of Nepal and abroad... There [were but]...indications of growing inequality, spatial and social, within the region, the district, and the village, and one would anticipate a picture of growing inequality from any contemporary village study. (Seddon, 2001, pp. 117-118)

This finding exactly corroborates to Norbert Elias's assertion that an account of longterm social change either notices "increased differentiation and integration" as well as "decreased differentiation and integration" (Elias, 1994, p. 182). Concurrent to this broad observation, Blaikie and his colleagues' re-study also found that, over a period of more than 20 years, there remarkably lacks change in the class structure (the pattern of households' classes). The nonfarm income played a greater role in supporting households and in providing an income. In the meantime, there was a level of increase in agricultural commodity production. However, they concluded, rural capitalism had failed to develop in either the forces of production or the relations of production; circumstances for individual migration had proven considerably more positive than anticipated, and the resulting remittances had allowed the preservation or even strengthening of the middle class (Blaikie et al., 2002, pp. 12621265).

Blaikie and his colleagues included class analysis as an integral part of their analysis without losing sight of a wider context (of dependent relationships). This was precisely the important analytical trope that Macfarlane $(1976,2001)$ missed out completely, as our aforementioned discussion suggests. However, both Macfarlane (2001) and Blaikie et al.'s (2002) accounts grossly ignores a pivotal role the market dynamics plays in shaping lives and livelihoods at the local level. Their systematic omission of the importance of the market (or the changing forms of market relations) in bringing longterm social change in contemporary rural Nepal is, thus, striking. Both Macfarlane (2001) and Blaikie et al. (2002) frequently mention the changing consumption behaviour, rising levels of expenditure (and the latters even talk about the increasing importance of commodity production); however, none of the two accounts adequately weave the market (or market relations) into the framework of analysis.

Trajectory 3. Eight years after the publication of Blaikie and his colleagues' reflective account, discussed above, Youba Raj Luintel, a sociologist from Tribhuvan University, in his doctoral research work, analyzes the relationship between expansion of the capitalist market in Nepal's agricultural sector and the resultant structural social change in a village in the vicinity of Kathmandu. He 
studied the case of the Mahesh Khola ${ }^{2}$ valley, west of Kathmandu, during a period of more than two decades (1985-2008) and examined the expansion of agricultural markets as a mechanism to transform rural livelihoods. In his research entitled "Capitalism and Underdevelopment in Rural Nepal: Market Relations, Inequality and Social Change in 'Mahesh Khola'," Luintel (2010) demonstrates how a development model that defined commodification of agriculture as the real development of the rural sector created a development paradox by bringing several social disruptions and aggravating existing social inequalities. He argued that neoliberal policies promoting market-centred development failed to take into account that markets it promotes are socially embedded in unequal power relations.

The exacerbation of social inequality created by this development model has several manifestations. As the case of Mahesh Khola illustrates, it includes (a) the radical restructuring of rural labor through unprecedented intra-class differentiation, notably through the emergence of a wealthier fraction within the working class, (b) the transformation of part of the traditional rural elite into a modern capitalist upper class, closely connected with this transformation;

2. A cluster of several villages in the foothills of Central Nepal, "Mahesh Khola" is a fictive name that represents an area located 25 to $30 \mathrm{~km}$ west of Kathmandu. This is a small river valley made up of two streams, which make its topography rugged, composed mainly of river banks and their constituent hillocks (with slopes predominating over flat river banks), at an elevation of between 950 to $1,700 \mathrm{~m}$. Note that Mahesh Khola is the same cluster of villages where Luintel had carried out his dissertation research for Master's thesis (Luintel, 1990, also see Luintel 1994). and (c) the progressive relocation (or selfdisplacement) of this modernised upper class to the capital city of Kathmandu (Luintel, 2010).

In this study, Luintel (2010) exposes how these long-term social changes are the outcomes of the accumulation and transfer of rural surplus to the metropolis urban centres. While a part of this surplus is retained by the rural working class and transferred to Kathmandu mainly through consumption of nonessential goods and services. A part of the surplus is spent on increasingly expensive agricultural inputs, such as pesticides and fertilisers. However, a large proportion of this surplus, Luintel (2010) illustrates, is expropriated by the actors who monopolise the access to agricultural markets: the modern indigenous upper class and the Indian traders who have control over the highly asymmetric core-periphery relation characterising market exchanges between Nepal and India. Moreover, the surplus diverted to the capital is often invested unproductively in real estate and urban residences, while the rural sector where the surplus is produced suffers from chronic disinvestment, social disruption and underdevelopment. Luintel's research draws four important conclusions, as follows:

The model of development that has been fostered in Mahesh Khola with greater emphasis on commodity production and profit making, in a period of more than two decades, has significantly improved the livelihood conditions of rural households. This is one facet of the long-term social change taking place in Nepal's countryside.

After two decades of persistent emphasis on production for sale, commercialisation of agriculture and profit-making from vegetables (1985-2008), the people of Mahesh Khola are now motivated to start a nonfarm livelihood 
in Kathmandu. Their regular exposure to the urban cosmopolitan life of Kathmandu (in or around the Kalimati vegetable market) has seduced the rural populace to cosmopolitanism in such a profound manner that they would like to make a fresh start in their lives and livelihoods away from agriculture sector. In Norbert Elias's argument line, such a shift in the lifestyle embodies profound characteristics that Nepal's countryside is going through.

A model of development, a neoliberal kind in Luintel's analogy, has deepened social inequality in Mahesh Khola by exacerbating class inequalities, at the intersection of existing social asymmetries of other kinds, notably caste, ethnicity and gender. From the prism of a long-term structural social change as propagated by Norbert Elias, this is one of the telling stories that contemporary social science may pursue further.

This way, the recent trajectories of capitalist development in Mahesh Khola have eventually resulted in a process of social differentiation connected with the transfer of economic surplus generated in agriculture and rural sector: from the farmers to the traders, and then from rural peripheries to the urban metropolis. In the long run, the rural peripheries are left underdeveloped due to the lack of productive investments, largely because the rural surpluses are predominantly transferred to the urban centres, and from there to the metropolis (Luintel, 2010; see also Amin, 1972 and Frank, 1967).

\section{Conclusion}

In these lights, such a durable social change unfolds in a long-term. Social change should be sociologically informed in the sense that social change needs to be examined in social structures and institutions. At its empirical ground, this paper argues that one cannot ignore the structural alteration that long-term social change eventually brings about in the case of rural Nepal. Further, an embedding class analysis in a broader historical context of evolving market dynamics could be two arenas of meaningful social change studies. The underlying belief on such an assertion on social change would eventually represent widening and deepening social inequality on the ground.

Macfarlane (1976) together with Blaikie and his colleagues' accounts (Blaikie et al., 1980) suffer overwhelmingly from the then popular structural approach of the 1980s, thus missing entirely the agency people can (and do) exercise within the structural constraints. From the vantage point of the present paper, their overt emphasis on decline, crisis and underdevelopment, instead of social change, made their accounts utterly political-economic. Blaikie and his colleagues' re-study (Blaikie et al., 2002), however, vividly draws our attention to the salience of widening social inequality in countryside Nepal, amidst the claims that livelihood conditions have slightly improved because of livelihood diversification and commodification of economy, an issue Macfarlane failed to acknowledge.

In this light, Luintel's (2010) key contributions can be summarised in two points First, his study demonstrates how the processes of social differentiation, mainly changing class relations serve as the mechanism for the accumulation and transfer of rural surplus from the working class to the elite sections of the society (Wright, 2009; Burris, 1987; Marx, 1971 [1867]), and how this accumulation is finally concentrated by the core actors of the capitalist markets.

Second, Luintel's study has sought to demonstrate that the extraction and transfer 
of rural surplus are largely a result of asymmetric core-periphery market relations (Naustdalslid, 1977, Wallerstein, 1974 \& Dos Santos, 1970) and the deepening of processes of social differentiation, particularly class inequalities (Emmanuel, 1972, Dos Santos, 1970). His study expands our understanding of how capitalist markets, that are socially embedded and interwoven in a mutually reinforcing asymmetric relationships of coreperiphery type, entirely serve the interests of the capitalist centres, a process that eventually drives and shapes the pattern of long-term structural social change of nonrecurrent type (Elias, 1994) through the process of social divergence, contradictions and disruptions.

My conception of social change is mainly informed by Elias's (1994) arguments that social change is not always essentially evolutionary; but mainly structural and transformative where he looks for "figurational change" (p. 184) over a longterm. Elias's conceptualisation of social change brings me closer to class analysis as the structural social change in society in the specific circumstances of countryside Nepal.

This article demonstrated that in order to develop a proper understanding of rural social change one needs to put agricultural markets at the centre of its analysis (AkramLodhi, 2001, Crow 2001 \& Harris-White 1999). Since the market is not only a process of exchange and economic transaction but also, vitally and more implicitly, the market is the mechanism of profit making, surplus appropriation and transfer of the surplus. This larger process of economic structure, this article argues, gets reflected in the changing class formation of any society, as is the case of Mahesh Khola.
Hence, class formation together with its dynamic articulation to capitalist worldeconomy, shapes the flow of surplus, which in the long-term transforms the very configuration of society, a process called social change (Elias, 1994). In order to facilitate our understanding of the capitalist market formation in the peripheral hinterlands (Bharadwaj, 1985) the subsequent sections of this article will combine arguments from a body of literature, the embeddedness and connectedness of global and peripheral markets together with a class analysis of structural social change.

\section{References}

Akram-Lodhi, A. H. (2001). 'We earn only for you': peasants and 'real' markets in Northern Pakistan,' Capital and Class, 25(2), pp. 79108.

Amin, S. (1972). 'Underdevelopment and dependence in Black Africa: Historical origin,' Journal of Peace Research, 9(2), pp. 105-120.

Barth, F. (1967). 'On the study of social change,' American Anthropologist, 69(6), pp. 661-669.

Bharadwaj, K. (1985). 'A view on commercialisation in Indian agriculture and the development of capitalism,' Journal of Peasant Studies, 12 (4), pp. 7-25.

Blaikie, P., John, C. \& David, S. (1980). Nepal in crisis: Growth and stagnation at the periphery. Oxford: Claredon Press (reprint by Oxford University Press, Delhi). p. 5.

Blaikie, P., John, C. \& David, S. (2002). 'Understanding 20 years of change in westcentral Nepal: Continuity and change in lives and ideas,' World Development, 30(7), pp. 1255-1270.

Bottomore, T. (1987). Sociology: A guide to problems and literature, $3^{\text {rd }}$ ed. London: Allen and Unwin. 
Boudon, R. (1986). Theories of social change: $A$ critical appraisal. Cambridge: Polity Press.

Burris, V. (1987). 'The Neo-Marxist synthesis of Marx and Weber on class', in N. Wiley (ed.), The Marx-Weber Debate. Newbury Park, CA: Sage Publications, pp. 67-90.

Campbell, B. (2001). 'Locating population and resources (Some responses to Alan Macfarlane's 'Sliding down hill'),' European Bulletin of Himalayan Research, 20-21 (double issue), pp. 110-112.

Chirot, D. (1977). Social change in the twentieth century. New York: Harcourt Brace Jovanovich.

Collins, R. (1990). 'Market dynamics as the engine of historical change,' Sociological Theory, 8(2), pp. 111-135.

Crow, B. (2001). Markets, class and social change: Trading networks and poverty in rural South Asia. New York: Palgrave.

Dahrendorf, R. (1959). Class and class conflict in industrial society. London: Routledge and Kegan Paul (originally published in German in 1957).

Santos, T. D. (1970). 'The structure of dependence,' The American Economic Review, 60(2), pp. 231-236.

Elias, N. (1994). The civilizing process: The history of manners and state formation and civilization, first English ed. Oxford: Blackwell (originally published as Uber den Prozess der Zivilisation as two separate volumes in 1939 by Haus zum Falker, Basel).

Emmanuel, A. (1972). Unequal exchange: A study of the imperialism of trade. New York: Monthly Review Press.

Etzioni-Halevy, E. (1981). Social change: The advent of maturation of modern society. London: Routledge \& Kegan Paul.
Frank, A. G. (1967). Capitalism and underdevelopment in Latin America. New York: Monthly Review Press.

Hagen, E. E. (1962). On the theory of social change. Illinois: The Dorsey Press, Inc.

Harriss-White, B. (1999). 'Power in peasant markets', in B. Harriss-White (ed.), Agricultural Markets from Theory to Practice: Field Experience in Developing Countries. London: Macmillan Press Ltd, pp. 261-286.

Hawley, A. H. (1978). 'The presidential address: Cumulative change in theory and in history,' American Sociological Review, 43(6), pp. 787-796.

Hernes, G. (1976). 'Structural change in social processes,' The American Journal of Sociology, 82(3), pp. 513-547.

Holton, R. J. (1985). The transition from feudalism to capitalism. London: Macmillan.

Jordan, T. \& Pile, S. (2002). Social change. Oxford and Cambridge: Blackwell Publishers with The Open University.

Lenski, G. (1976). 'History and social change,' The American Journal of Sociology, 82(3), pp. 548-564.

Luintel, K. B. (2001). 'Micro truth - But what about the macro? (Some responses to Alan Macfarlane's 'Sliding down hill'),' European Bulletin of Himalayan Research, 20-21 (double issue), pp. 112-113.

Luintel, Y. R. (1990). People's participation through small groups in rural development, an unpublished MA dissertation submitted to Tribhuvan University, Kathmandu.

Luintel, Y. R. (1994). Group process for people's participation in rural Nepal: reflections from a micro level study, Occasional Papers in Sociology and Anrhropology, 4, pp. 110-123. 
Luintel, Y. R. (2010). Capitalism and underdevelopment in rural nepal: market relations, inequality and social change in 'Mahesh Khola,' a PhD thesis submitted to the Graduate School of Geography, Politics and Sociology, Newcastle University, United Kingdom.

Macfarlane, A. (1976). Resources and population: A study of the Gurungs of Nepal. Cambridge: Cambridge University Press (re-published by Ratna Pustak Bhandar in 2003).

Macfarlane, A. (2001). 'Sliding down hill: Some reflections on thirty years of change in a Himalayan village,' European Bulletin of Himalayan Research, 20-21 (double issue), pp. 105-124.

Marx, K. (1971) [1867] Capital: A critical analysis of capitalist production (Vol. 1). London: George Allen \& Unwin Ltd. (translated by Samuel Moore and Edward Aveling from the third German edition and edited by Frederick Engels).

Moore, W. E. (1963). Social change. Englewood Cliffs, NJ: Prentice-Hall.

Naustdalslid, Jon. 1977. 'A multi-level approach to the study of center-periphery systems and socio-economic change,' Journal of Peace Research, 14(3), pp. 203-222.

Noble, T. (2000). Social theory and social change. London: Macmillan Press Ltd.

Parsons, T. (1970). 'Some considerations on the theory of social change', in S. N. Eisenstadt (ed.), Readings in Social Evolution. Oxford and New York: Pergamon Press, pp. 95-139.
Seddon, D. (2001). 'The contradictions of rural transformation in Nepal (Some responses to Alan Macfarlane's 'Sliding down hill'),' European Bulletin of Himalayan Research, 20-21 (double issue), pp. 117-122.

Smelser, N. J. (1967). 'Processes of social change', in N. J. Smelser (ed.), Sociology: An Introduction. New York: John Wiley \& Sons, pp. 709-762.

Smith, A. D. (1973). The concept of social change: A critique of the functionalist theory of social change. London: Routledge \& Kegan Paul Ltd.

Swanson, G. E. (1971). Social change. Glenview, Illinois: Scott, Foresman and Company.

Sztompka, P. (1993). The sociology of social change. Oxford and Cambridge: Blackwell.

Wallerstein, I. (1974). 'The rise and future demise of the world capitalist system: Concepts for comparative analysis,' Comparative Studies in Society and History, 16(4), pp. 387-415.

Wright, E. O. (2009). 'Understanding class: Towards an integrated analytical approach,' New Left Review, 60, pp. 101-116.

Zollschan, G. K. \& Hirsch, W. (1964). Explorations in social change. Boston: Houghton Mifflin. 